\title{
The significance of the 1971 flank eruption of Etna from volcanological and historic viewpoints
}

\author{
Stefano Branca*,1, Daniele Musumeci² ${ }^{2}$,uigi Ingaliso ${ }^{2}$ \\ (1) Istituto Nazionale di Geofisica e Vulcanologia, Osservatorio Etneo-Sezione di Catania \\ (2) Università di Catania, Dipartimento di Scienze Umanistiche, Piazza Dante 32, Catania, Italy
}

Article history: received March 29, 2021; accepted September 28, 2021

\begin{abstract}
The 1971 eruption represents a benchmark in the recent history of Etna volcano. From a volcanological point of view, this eruption was characterised by complex intrusive dynamics associated with significant ground deformation that induced the activation of the Moscarello seismogenic fault and the formation of a new summit crater: the Southeast Crater. At the same time, the 1971 event marks an important change in the eruptive style and composition of the magma towards products richer in K. It is no coincidence that, over the next fifty years, there would be an increase in the frequency of summit and flank eruptions and associated output rate. From an historical viewpoint, the eruptive event of 1971 was the first important flank eruption studied by the International Institute of Volcanology: the analysis of the scientific articles on this activity reveals a greater multidisciplinary content in the descriptions and explanations of volcanic activity. Particularly important were the collaborations of British and French research groups that, together with their Italian colleagues, succeeded in giving a complete picture of the eruption and describing the state of knowledge on the Sicilian volcano. The multidisciplinary methodology used to study this eruption is still valid today.
\end{abstract}

Keywords: Etna volcano; Flank eruptions; Multidisciplinary data; History of volcanology.

\section{Introduction}

Mount Etna volcano, in eastern Sicily, is known world-wide for its almost continuous eruptive activity from the summit craters and for less frequent flank eruptions related to magma intrusion along the main rift zones of the volcano [Branca et al., 2011; Azzaro et al., 2012]. In particular, the generally low magnitude of the explosive summit eruptions, characterised by the typical Strombolian activity, and the effusive style of the flank eruptions have favoured the observations and studies of the eruptive phenomena of Etna since historical time [Tanguy, 1981; Guidoboni et al., 2014]. In fact, Etna volcano has the longest record of historical documentations of its activity dating back to the VIII century BC. Even though the historical sources span just less than three millennia, only after the mid- $17^{\text {th }}$ century did the observations and descriptions of the summit and flank eruptions become more complete and accurate [Tanguy, 1981; Branca and Del Carlo 2004, 2005; Tanguy et al., 2012; Branca and 


\section{Stefano Branca et al.}

Abate 2019]. In particular, in this age-old history of observation, the highly destructive 1669 flank eruption [Branca et al., 2013, 2015] represents a turning point in the approach to studying eruptive phenomena of Etna that gradually improved the quality and completeness of information, by adopting a scientific approach for the first time [Branca and Del Carlo, 2004]. In this frame, the manuscript of Giovanni Alfonso Borelli (1670) on the 1669 eruptions is the first scientific study in which the author proposes the first quantitative explanation of the eruptive processes [Morello, 2001; Guidoboni et al., 2014]. During the $18^{\text {th }}$ century, the activity of the volcano was observed and described in narrative-like studies by several authors, but Giuseppe Recupero (1720-1778), was the only one to systematically compile a detailed chronicle of the events that were reported in the catalogue of the eruptions published posthumously [Recupero, 1815].

Starting from the $19^{\text {th }}$ century, the cartographic mapping of the volcanic products represented a new approach to studying the eruptions thanks to the realization of the first topographic and geological maps of Etna, at 1:50.000 scale, by the German scientist Sartorius von Waltershausen (1809-1876) published between 1844 and 1861 [Sartorius 1848-61; Branca and Abate, 2019]. During the second half of the $19^{\text {th }}$ century, Orazio Silvestri (1835-1890) introduced for the first time a modern approach to study Etna's eruptions starting from the 1865 flank eruption [Silvestri, 1866]. The new approach comprised cartographic mapping of the volcanic products, updating the work of Sartorius, and the physical-chemical analyses of the rocks. In particular, Silvestri performed the earliest petrographic study of Etna volcanics related to the 1886 flank eruption [Silvestri, 1886, 1893] and the cartographic mapping of the lava flows enabled the author to calculate the lava volume for the first time [Abate et al., 2013]. The idea of "monitoring" the eruptive activity of the volcano was the brainchild of Silvestri, who informed the local and national authorities through scientific reports, together with the proposal to create a volcanological observatory on Etna [Cristofolini, 2016; Musarra, 2018]. Indeed, Silvestri also introduced the study of the geodynamic phenomena accompanying the onset of the 1883 flank eruptions due to the installation of the first seismographic network on Etna [Silvestri, 1883].

During the first half of the $20^{\text {th }}$ century, the scientific project of studying and monitoring the eruptions of Etna defined by Silvestri was developed further by Gaetano Ponte (1876-1955) with the foundation of the Volcanological Institute of Catania University, one of the first university structures in Europe that at the time focused on investigating volcanoes [Bonaccorso and Branca 2005; Cristofolini 2016]. In those years, the numerous flank eruptions were studied by several scientists, the most notable among which were A. Riccò, G. Ponte, G. Platania, O. De Fiore, G. Imbò, G. Cumin, S. Cucuzza Silvestri, F. Stella Starabba and P. Vinassa de Regny [Branca and Del Carlo, 2005], whose research papers mainly focused on the reconstruction of the chronology of the eruptive phenomena and secondarily the petrography of the volcanic products. On the whole, this methodological approach to study the flank eruptions of Etna followed the one defined by Silvestri in the second half of the 19th century. A typical example of this kind of study was that by Cumin [1954] on the 1950-51 flank eruption, in which the author summarised the data collected during the event through a diagram on the evolution of the eruption, reporting the seismicity and the different phases of the effusive and explosive activities, and completing the information with the petrography and the map of the lava flows (Figure 1).

During the second half of the $20^{\text {th }}$ century, the development of a more contemporary approach towards volcanological studies on Etna was the work of Alfred Rittmann (1893-1980), who had the idea of creating an international research institute in Catania in the 1960s [Musumeci et al., 2021]. Rittmann introduced a multidisciplinary approach by combining interdisciplinary researches in the study of volcanism with the aim of quantifying the phenomena and investigating the relationship with tectonics.

In this paper, we examine the case of the 1971 flank eruption, the first important Etna eruption investigated through a multidisciplinary approach by a team of national and international researchers. In particular, we have analysed the contemporaneous sources in order to: a) reconstruct the scientific context of the time; b) reconstruct the eruptive phenomena on the basis of the current scientific knowledge; c) define the significance of the 1971 eruption from a volcanological and historical point of view. 


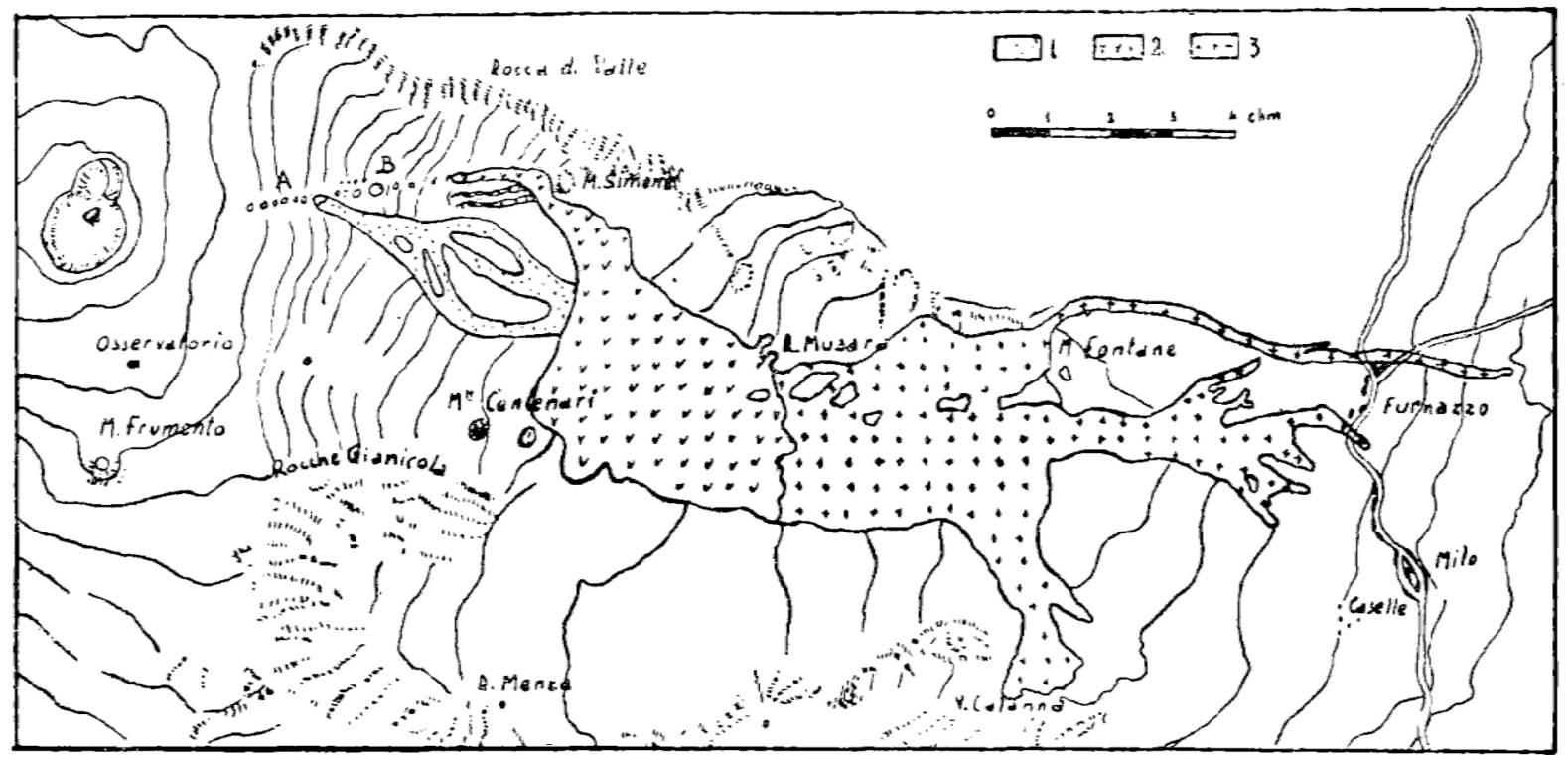

Figure 1. Map of the 1950-51 lava flows and of the eruptive fissure of Cumin [1953-54]. The author reports three different evolutionary phases of the lava field.

\section{The 1971 flank eruption}

After the end of the long-lasting 1950-51 flank eruption, Etna volcano underwent a lengthy period of summit eruptive activity that involved both the NE and the Central craters [Branca and Del Carlo, 2005]. The summit activity was interrupted by a short-lived flank eruption between the 1 and 2 of March, 1956 with the opening of an eruptive fissure at $2750 \mathrm{~m}$ a.s.l. in the western wall of the Valle del Bove, producing a $2 \mathrm{~km}$-long lava flow and later by a long-lasting flank eruption occurring in 1968. In particular, on 7 January an effusive vent opened at $2500 \mathrm{~m}$ a.s.l. in the western wall of the Valle producing lava flows in the valley up to 4 May. This flank eruption was followed by the opening of another eruptive fissure at $2850 \mathrm{~m}$ a.s.l. on the east base of the summit cone, generating lava flows in Valle del Bove until the first half of July. In this period, the NE Crater was characterised by almost continuous and low rate lava effusion from vents along the base of the cone and by intense strombolian activity that increased the summit scoria cone starting from 1966. The Central Crater also underwent important morpho-structural changes during the 1960s with the presence of three main areas of activity: Voragine to the east (formed in 1945), a new cone to the south-west (Bocca of 1964, formed precisely during the paroxysmal activities of 1964) and the Bocca Nuova to the north-west [Guest, 1973]. The latter first appeared in June 1968 when a 6-8 $\mathrm{m}$ wide pit crater formed on the west side of the Central Crater, named Bocca Nuova. During the winter of 1970, the new pit collapsed to form a 100 $\mathrm{m}$ wide and roughly $300 \mathrm{~m}$ deep crater [Guest, 1973].

The eruptive activity of NE Crater ended in March 1971, but then according Rittmann and Tazieff - without any seismicity being felt - two short radial eruptive fissures opened at the southern base of the summit cone during the afternoon of 5 April [Rittmann et al., 1971; Smithsonian Institute CSLP, 1972]. During the eruption only two seismic stations were operating, in Catania and Acireale (Serra la Nave was out of order, see Figure 2), for this reason low magnitude seismicity on the upper flanks may not have been recorded [Azzaro and Barbano, 1996]. In particular, a NNW-SSE fissure formed at $3000 \mathrm{~m}$ a.s.l., the so called Vulcaloro vent, and a N-S fissure formed at 2950-2975 m a.s.1, the so-called Observatory vent (Figure 3). The two fissures were characterized by strombolian activity from several vents that generated coalescent scoria cones along the fissures and intense effusive activity producing an extensive lava field, mainly towards the south and secondarily along the western wall of the Valle del Bove. The Vulcaloro fissure activity ended on 16 April. In the afternoon of 21 April, a moderate earthquake occurred in the lower east flank (Figure 2) that caused damage to the houses of Macchia village and in the neighbouring districts of Giarre [Riuscetti and Di Stefano, 1971]. A third eruptive fissure opened on 22 April at about $3050 \mathrm{~m}$ a.s.l. upslope from the Observatory vent along the same fracture system, (Cratere $n^{\circ}$ III in Figure 3). Strombolian activity from several vents 
Stefano Branca et al.

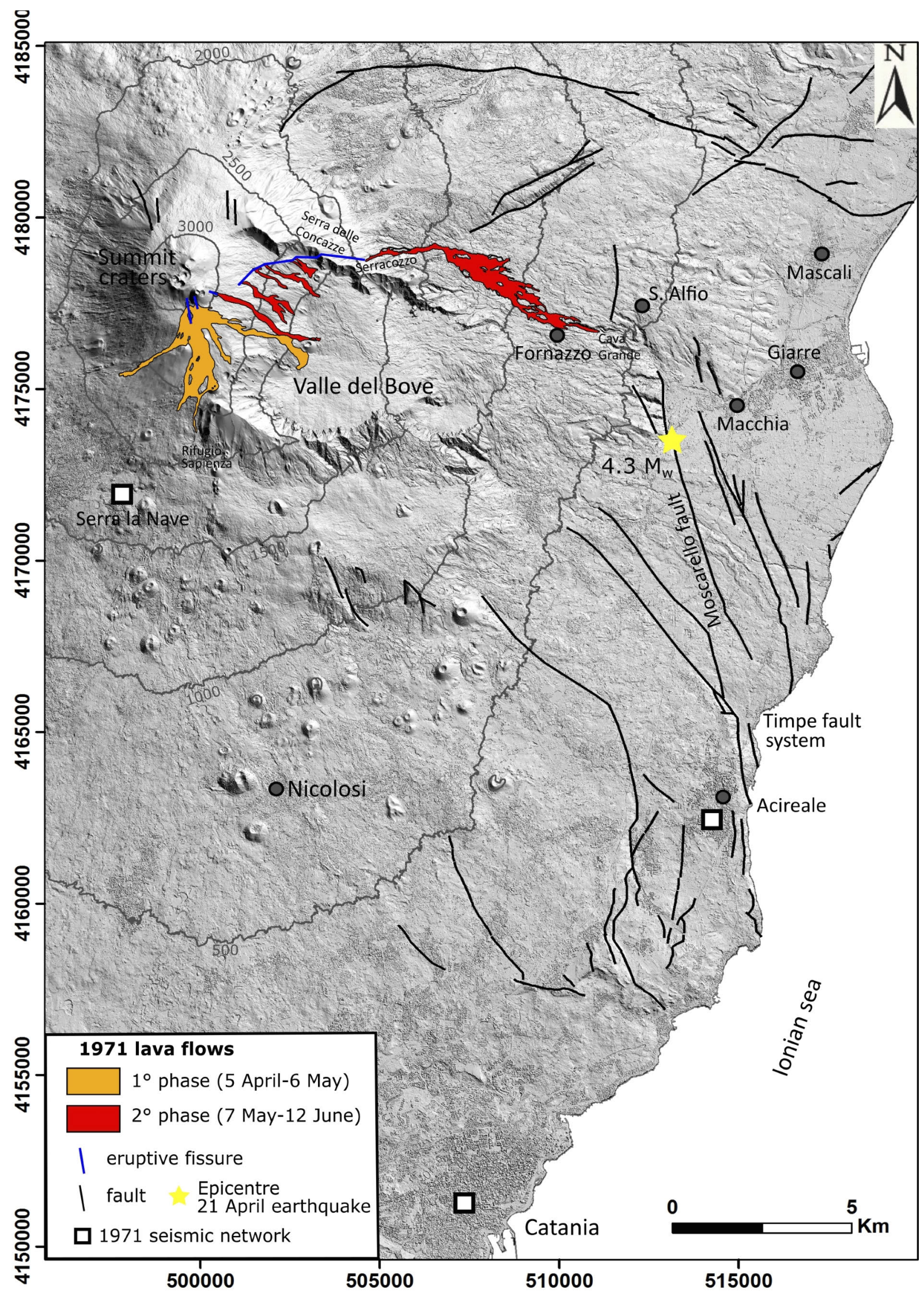

Figure 2. Map of the 1971 flank eruption and location of the epicenter of 21 April earthquake and of the seismic network consisting of one-component analog stations active in 1971. 
generated coalescent scoria cones and the emission of lava flows partially superimposed the Observatory vent expanding westward. Activity of these fissures ended on 6 May, producing a 4-km long compound lava field that covered an area of $3 \mathrm{~km}^{2}$ and reached minimum elevations of $2175 \mathrm{~m}$ a.s.l. upslope from the Rifugio Sapienza tourist area and $1675 \mathrm{~m}$ a.s.l. in Valle del Bove (Figure 3). During the emplacement of the lava flows, the historical volcanological Observatory of Catania University was destroyed together with the upper station of the cable car and several pylons. In the late evening of 4 May, a fourth eruptive fissure, WNW-ESE trending, opened at 2900$2880 \mathrm{~m}$ a.s.l. at the eastern base of the summit cone. Effusive activity of this fissure produced a short-lived lava flow in Valle del Bove that reached the minimum elevation of $1625 \mathrm{~m}$ a.s.l. Activity of this fissure ended around midnight of 6 May. On the whole, during the eruptive activity of these fissures significant ground deformation occurred, generating a radial pattern of dry fractures in the southern slope of the summit cone that developed down to Mt. Frumento Supino and Piano del Lago locality (Figure 3).

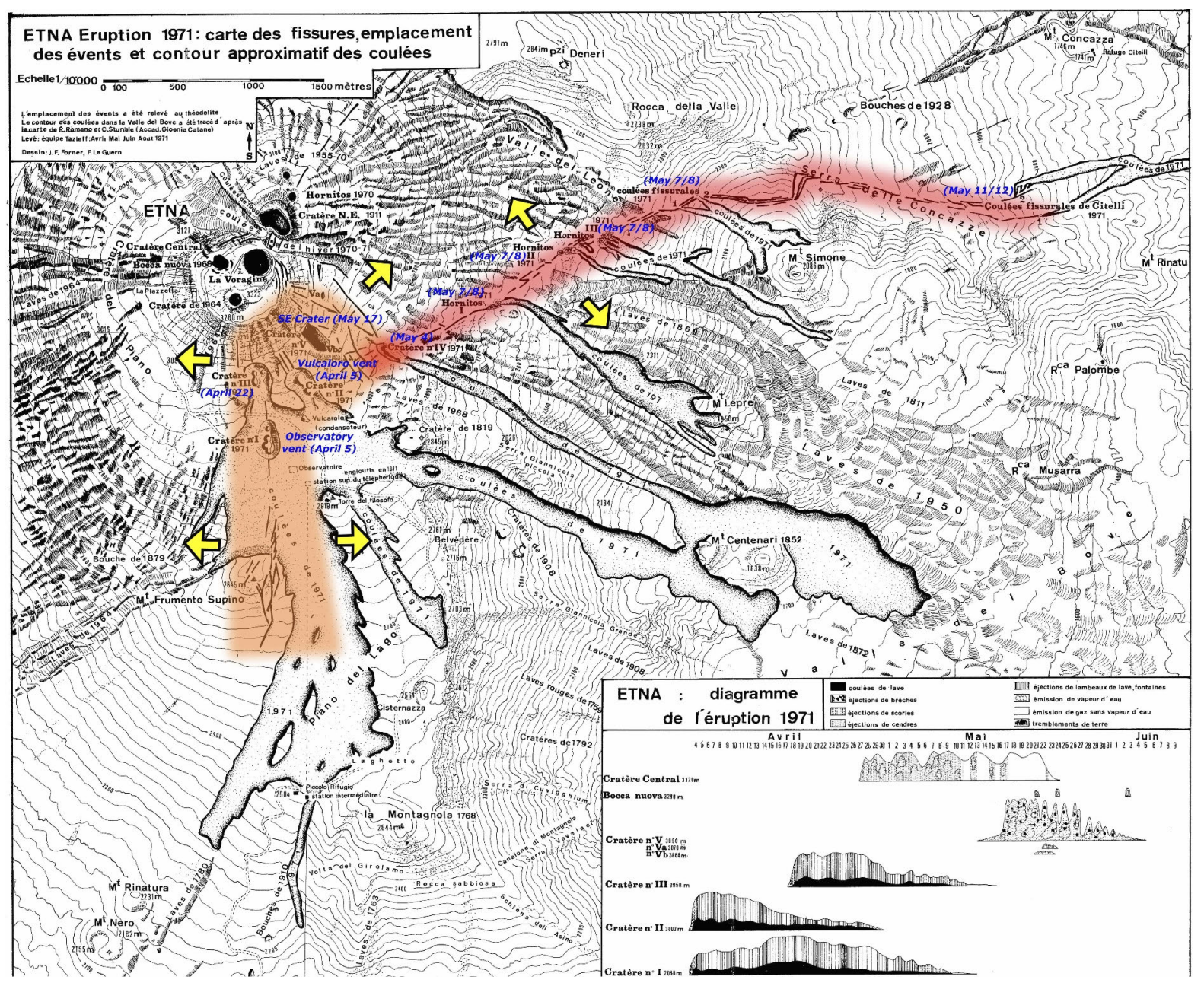

Figure 3. Map of 1971 eruption modified by Le Guern [1972], highlighting the dry fissure systems of the first and second phases in orange and red, respectively. The yellow arrows indicate the tensile opening related to the dyke intrusions. In blue, we have reported the name of the main vents and the opening dates of all fissures.

After a short period of stasis, the eruptive activity resumed late on 7 and 8 May due to the formation of a WSWENE trending fracture system developed from about $2900 \mathrm{~m}$ a.s.l. toward the Valle del Leone associated with the opening of five eruptive vents, located between $2680 \mathrm{~m}$ and $2300 \mathrm{~m}$ a.s.l. These fissures produced short lava flows along the western wall of the Valle del Bove up to 17/18 May (Figure 3). The ENE migration of the feeder dyke intersected the northern wall of the Valle del Bove at Serra delle Concazze locality, generating the opening of two 


\section{Stefano Branca et al.}

other short eruptive fissures during the night of 11/12 May. These fissures were located at $1840 \mathrm{~m}$ and $1800 \mathrm{~m}$ a.s.l. at Serracozzo locality and were characterized only by effusive activity. Intense lava effusion generated lava flows channelized in the Cubania valley expanding toward the lower east flank. During the progression of the lava flows several cultivated lands, farmlands and roads were destroyed and the village of Fornazzo was threatened for the first time on 21 May (Figure 2). A few meters wide pit crater opened on 17 May at the SE base of the summit cone at 3000 $m$ a.s.l. during this period of intense effusive activity (Figure 4) [Walker, 1973a]. In the following days, the pit crater reached a diameter of about $200 \mathrm{~m}$ and was characterized by continuous and intense ash emission up to 27 May, then becoming sporadic up to 9 June. The lava flows from the effusive vents of Serracozzo reached the Cava Grande gorge toward the end of May at a minimum elevation of $600 \mathrm{~m}$ a.s.l. showing a maximum length of $7 \mathrm{~km}$ (Figure 2). Lava effusion ended on 12 June. In all, the eruption lasted 69 days during which about $3 \times 10^{6} \mathrm{~m}^{3}$ of pyroclastics and $75 \times 10^{6} \mathrm{~m}^{3}$ of lava were emitted. The lavas covered a total area of $7.5 \mathrm{~km}^{2}$ [Rittmann et al., 1971].

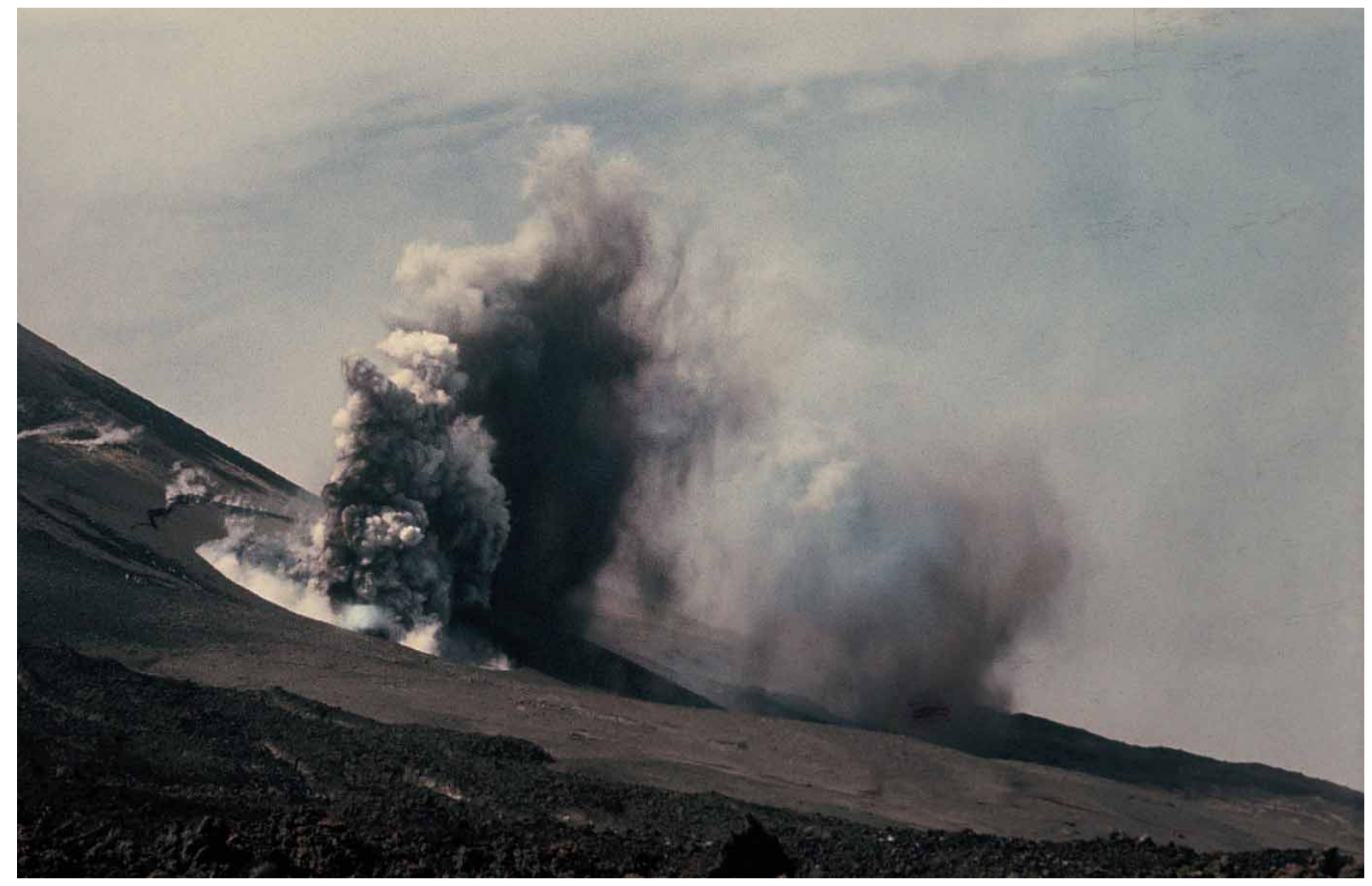

Figure 4. Formation of the South-East Crater on the lower slope of the summit cone at 3000 m elevation (May $18^{\text {th }}, 1971$, photograph courtesy of J. C. Tanguy).

\section{A multidisciplinary approach to study Etna: collaboration among international specialists}

In 1958, the Swiss volcanologist Alfred Rittmann arrived in Catania and founded an International Institute at the foot of the volcano. The institute was called Institut International de Recherches Volcanologiques (I.I.R.V.), and was initially based at the volcanological institute of the University of Catania. It became independent from the university in 1968, and its name was changed to Laboratoire International de Recherches Volcanologiques of the Consiglio Nazionale delle Ricerche (CNR) under the patronage of UNESCO. After two years, the Laboratory was transformed into the International Institute of Volcanology (IIV-CNR) [Musumeci et al. 2021].

Rittmann was president of the AIV (Association International de Volcanologie) from 1954 to 1963 and for this initiative he gathered the support of talented scientists such as Haroun Tazieff (1914-1998) and Giorgio Marinelli 
(1922-1993). Each brought their own cultural backgrounds, forming students and research teams. Rittmann is considered one of the fathers of contemporary European volcanology: many of the innovative elements developed by Rittmann provided an important route for volcanological research from the 1930s to the 1970s and, still today, his intuitions represent the basis for some following research. The main innovation was the integration of volcanology stricto sensu together with magmatology and local and regional tectonics. His broad scientific vision, including a planetological hypothesis [Kuhn and Rittmann, 1941], an orogenetic cycle and original mineralpetrographic concepts [Rittmann Norm, Rittmann et al., 1973], constitutes a unitary paradigm, called Magmatological Tectonics [Musumeci et al. 2021]. Concepts from the philosophy of science and nature provide a unified framework for his paradigm. Many of his students began their studies with this vision, especially before the advent of the Plate Tectonics paradigm, with which Rittmann had an uncertain relationship [Rittmann, 1981]. His multidisciplinary approach and his use of multiple working hypotheses [Chamberlin, 1890] remain a philosophical-scientific incentive for research, just as his Norm and his Eruptions Diagrams, semi-quantitative diagrams useful for describing the variability of volcanic eruptive styles during an eruptive period [Lockwood and Hazlett, 2010].

Tazieff had been studying Etna since the late 1940s [Tazieff, 1984] and was present during the 1971 eruption with his research group. Tazieff is also considered one of the fathers of contemporary volcanology, though there is no general consensus on this point, since his scientific contribution has only recently been re-evaluated. An explorer and popularizer, he produced numerous documentaries on his countless expeditions, showing volcanoes to the public for the first time. As a scientist, he was a pioneer in studies on the role of gases in eruptive mechanisms [Elskens et al. 1964; 1968; Le Guern, 2007], on the presence of water in magmas, on underwater volcanism, on techniques for measuring variations in the magnetic field in relation to eruptive activity, and no less on the relationship between volcanology and plate tectonics. An eclectic character, he was an alpinist and speleologist, but also a sportsman, practising boxing and rugby (Centre Haroun Tazieff). Among the many volcanoes studied, Etna was certainly one of the most visited [Tazieff, 1972; 1984].

Another notable volcanologist was Marinelli, who was Director of the IIV-CNR during the 1971 eruption. A scientist who also possessed a great humanistic culture, he graduated in Florence in 1945 with a degree in Natural Sciences and a thesis on Petrography. He then worked in Pisa, at the Institute of Mineralogy and Petrography of Stefano Bonatti (1902-1968). He became assistant professor of Mineralogy and then professor of Petrography from 1948 to 1961, when he was appointed the first chair dedicated to this discipline in Italy. Through his cultural work, he brought Petrography closer to Petrology, thus uniting the accurate descriptive analysis of rocks with petrogenetic studies, affirming the necessary link between soil analysis, sampling and laboratory studies [Barberi and Innocenti, 1995]. He became a friend and collaborator with Rittmann, who became his tutor in volcanology, and gradually shifted his interests towards volcanology and elaborated the anatectic origin of Tuscan acid magmas. Marinelli's interest in volcanoes was also fuelled by his friendship with Tazieff: together they organized important expeditions to Afar (the first in 1967) to study the relationships between volcanism, geodynamics and magma evolution, at a time when the novelty was represented by Plate Tectonics [Tazieff et al. 1969]. On an institutional level, he was Director of the I.I.V. in Catania from 1967 to 1977 and Director of the Institute of Mineralogy and Petrography after Bonatti's death. During his life, he also devoted himself to studying the genesis of economically important minerals, such as uranium [Candela, 2019] and to Geothermal research.

The presence on Etna of important figures such as Rittmann, Tazieff and Marinelli helped volcanological studies to emerge from cultural provincialism and, for the first time, the volcano was studied in a multidisciplinary way by groups of Italians, French, British and Americans. Among the British was John Edward Guest (1938-2012). Graduating from University College London (UCL) in 1962, he remained with the university for almost 50 years. In that time, he established the emerging disciplines of planetary geology and physical volcanology at UCL. He was among the generation of scientists who recognized the importance of transforming volcanology into a physical discipline and, even though he described himself as a field geologist, he vigorously promoted advances in quantifying the effusive behaviour of volcanoes [Kilburn et al., 2012]. This path in the advancing of volcanological studies, pioneered by Rittmann many decades earlier [Rittmann, 1931], found a very creative and inspirational interpreter in G. P. L. Walker (1926-2005) [Guest et al., 2003; Self and Sparks, 2006]. In 1973, Guest led the UK contribution to a 10-year Anglo-Italian project to investigate the evolution of Mount Etna. The collaboration led to the geological map of the volcano published in 1979 [Romano et al., 1979] and launched a new understanding of Etna's magmatic feeding system and eruptive dynamics [Chester et al., 1985]. 


\section{Stefano Branca et al.}

\section{Studies and experiments conducted during the 1971 eruption: the 1973 Volume}

As part of renewed interest in Etna's persistent activity, new experiments were carried out on the volcano. Some of these had already been initiated during the summit activities of the North-East Crater in the late 1960s, as well as during the formation of the Bocca Nuova in 1968. During those years, Tazieff worked extensively on Etna and led the French team. During the 1971 eruption, a group of scientists, called the International Volcanological Team, was active, organised by Tazieff and supported by Centre Nationale de Recherche Scientifique, Paris, Comissarat de L'Energie Atomique, Paris, and the IIV-CNR of Catania [Huntington, 1972].

The outcome of the collaboration between local and international scholars was a meeting at the Royal Society on 9 and 10 February 1972 organized by Professor J. Sutton, F.R.S., Dr J. E. Guest, Dr R. R. Skelhorn and Professor R. L. Wilson, on behalf of the Royal Society and of the Volcanic Studies Group of the Geological Society of London [Vincent, 1973]. The meeting was followed by a substantial volume [Guest and Skelhorn, eds., 1973] in which the researchers wrote a personal contribution, thus giving a complex and exhaustive picture of the 1971 eruption and the state of studies on Mount Etna. The papers summarize the state of knowledge of the structure, geological history and eruptive behaviour of the Etna volcano, as well as of the chemistry and physical properties of its magmatic products, both lavas and gases [Vincent, 1973].

A general geological picture of the volcano was given by Rittmann [Rittmann, 1973] and Cristofolini [Cristofolini, 1973]. In particular, Rittmann indicated Etna as the most interesting volcano considering a) its eruptive mechanisms; b) the origin and evolution of its magmas; c) its tectonic position in relation to the complex tectonophysics of the Mediterranean area [Rittmann, 1973]. Rittmann also stated that at that time there was no adequate geophysical monitoring system nor an updated geological study linked to petrographic and geochemical studies. The geochemical study of gases and fumaroles also needed to be enhanced. Tazieff contributed with some general considerations on Etna, on the 1971 eruption and on the relation of the volcano to regional tectonics [Tazieff and Le Guern, 1972; Tazieff, 1973]. Guest centred his analysis on the geological-structural setting of the volcano, with particular focus on the recent evolution of the summit area and making inferences on the structural modifications that would lead to the flank eruption of 1971 [Guest, 1973]. At the end of the volume, Grindley further elaborated on the development of Etna in relation to the tectonics of Sicily, the Tyrrhenian Sea and southern Italy. After outlining the complex volcano-tectonic history of Etna, he suggested that the monitoring of recent ground movements in the Mt Etna region by retriangulation, geodimeter lines, tiltmeters and tide gauges, would provide a measure of the secular strain pattern and eventually provide warning of crustal extension, volcano-tectonic doming and lava eruption [Grindley, 1973].

Petrographic and petrological studies were carried out on samples of the eruptive products of this eruption [Cristofolini, 1973; Romano and Sturiale, 1973, Tanguy, 1973], as well as experimental studies on the lavas emitted from the Serracozzo vents during the last eruptive phase. The lava products were collected from the flows and artificially cooled for examination, after which they were melted in the laboratory under atmospheric pressure [Downes, 1973]. Other quantitative studies, both in the field and in the laboratory, were also conducted on the rheology of Etnean lavas in motion, with attention to parameters such as viscosity, temperature, fluid dynamics and effusion rate [Booth and Self, 1973; Gauthier, 1973; Huntington, 1973; Walker, 1973b]. Walker's research on effusion rate as the main control on the distance that lavas travel would become a milestone on the subject in the following decades [Self and Sparks, 2006]. After studying the lavas emitted at the base of the North-East Crater between 1966 and 1971, it was possible for Gauthier, during the flank eruption, to study for the first time in the field the rheological properties of Etna's lavas during the different phases of a non-paroxysmal activity [Gauthier, 1973]. Instead, studies are reported on the cooled Etnean lavas using comparative analyses obtained by electron microprobe [Arculus, 1973] and paleomagnetic analysis [Tanguy and Wilson, 1973]. During the Etna activities of 1970 and 1971, Huntington experimented a new method of collecting and analysing volcanic gases [Huntington, 1973], concluding that the best way to compare analyses was in the atomic form because this eliminates secondary equilibration effects (Figure 4). Le Guern described how the study of the Etna gas phase [Le Guern, 1972], little developed previously, was carried out in those years by the French team [Le Guern, 1973]: in the paper presented, he analyses the difficulties of sampling in the gas phase and the results obtained during the experiments carried out in 1971. With the same aim, Sato and Moore [1973] joined the international team organised by Tazieff and measured magmatic gases by solid-electrolyte sensors on the NE side of the North-East Crater in July 1970 (Figure 4). 
During the final phase of the eruption, the pyroclastic deposit produced by emissions from the new explosion crater at the SE base of the central cone was also studied [Booth and Walker, 1973]. The volume concludes with a brief appendix [Walker, 1973a] that provides a general summary of the eruptive phases of the 1971 event. This was the first time in $20^{\text {th }}$ century that such a consistent and multidisciplinary effort was made to study an eruption and to understand the eruptive behaviour of Etna.

\section{Discussion}

Contemporary researchers defined "the eruption of April-June 1971 (as) the biggest event on Etna since the early 1950s" [Walker, 1973a], although the significance of this event in the recent eruptive history of the volcano could not have been imagined at that time. In fact, Tazieff reported: "I do not think that the 1971 eruption was either the most important or longest one Mt Etna has delivered this century" [Tanguy, 1973]. The following development of widespread geophysical and geochemical networks on Etna since the 1990s enabled better defining and understanding the feeder system structure, the intrusive phenomena processes and the relationship between the latter and the geodynamics of the volcano edifice that is involved in extensive flank instability of the eastern sector [Bonaccorso et al., 2004]. The new knowledge on Etna volcano obtained during the investigations of the last thirty years, together with the increase of the monitoring data, have allowed a clearer understanding of the role played by the 1971 eruption in the recent eruptive history of Etna from both a volcanological and historic point of views as reported below.

\subsection{Volcanological features}

The 1971 eruption was characterised by a very complex intrusive dynamics, separated by a brief stasis, involving both the eastern flank dynamics with the activation of the Timpe fault system and the summit area with the formation of a new summit crater, the so-called SE Crater. The earliest eruptive phase (5 April-6 May) was controlled by the magma intrusion from the upper portion of the summit craters conduit that produced a wide ground deformation of the entire SE slope of the summit cone, generating four short eruptive fissures trending from N-S to WNW-ESE, between $3000 \mathrm{~m}$ and $2880 \mathrm{~m}$ a.s.l. and a dry fracture system N-S oriented down to $2650 \mathrm{~m}$ a.s.l. (Figure 2) During this eruptive phase, a shallow earthquake of $\mathrm{M}_{\mathrm{w}} 4.3$ occurred at the Moscarello fault with an intensity (EMS) of VIII [Rovida et al., 2020]. The Moscarello fault represents the innermost element of the Timpe fault system, the most prominent structural feature of the volcano (Figure 5), which displaces the lower eastern flank by a $20 \mathrm{~km}$-long and $5 \mathrm{~km}$ wide belt of mainly extensional structures, striking from N to NW [Azzaro et al., 2012]. Direct correlations among intrusive processes and main earthquakes of the principal fault systems of Etna were clearly observed and geophysically monitored during the 2002-03 [Walter et al., 2005 and reference therein] and 2018 flank eruptions [Bonforte et al., 2019; Mattia et al., 2020]. Therefore, based on current knowledge it is possible to assume that the activation of the Moscarello fault can be attributed to the significant stress change in the upper part of the volcano due to the dyke intrusions of the first eruptive phase of the 1971 eruption.

The second eruptive phase was fed by an ENE trending magma intrusion from $2900 \mathrm{~m}$ a.s.l. down to $1800 \mathrm{~m}$ a.s.l. produced by a roughly $4.5 \mathrm{~km}$-long dyke that propagates horizontally, thereby generating several effusive vents at decreasing elevation between 7 and 12 May. According to Aloisi et al. [2006], these typologies of dyke supply the magma to the flanks from a deeper magma storage through the summit conduit zone. This type of intrusive mechanism has been modelled for the 1983, 1989, 1991-93 and 2002 flank eruptions by ground deformation data [Aloisi et al., 2006; Bonaccorso and Davis, 2004]. On 17 May, a pit crater formed at the intersection between the radial fractures opened on the SE slope of the summit cone and the ENE-oriented eruptive fissure at about $3000 \mathrm{~m}$ a.s.l. This pit crater, later named SE Crater (SEC) [Romano, 1981], in the following decades would become the most active of the summit craters of Etna, taking the place of the NE Crater formed in 1911 and characterized by an almost persistent activity until 1971.

The 1971 eruption is also considered a turning point in the recent eruptive history of the volcano. Indeed, following this eruption, a significant increase in the number of both summit and flank eruptions occurred, associated with an increase of the lava output rate [Wadge and Guest, 1981; Branca and Del Carlo, 2004, 2005; Harris et al., 2011]. 


\section{Stefano Branca et al.}

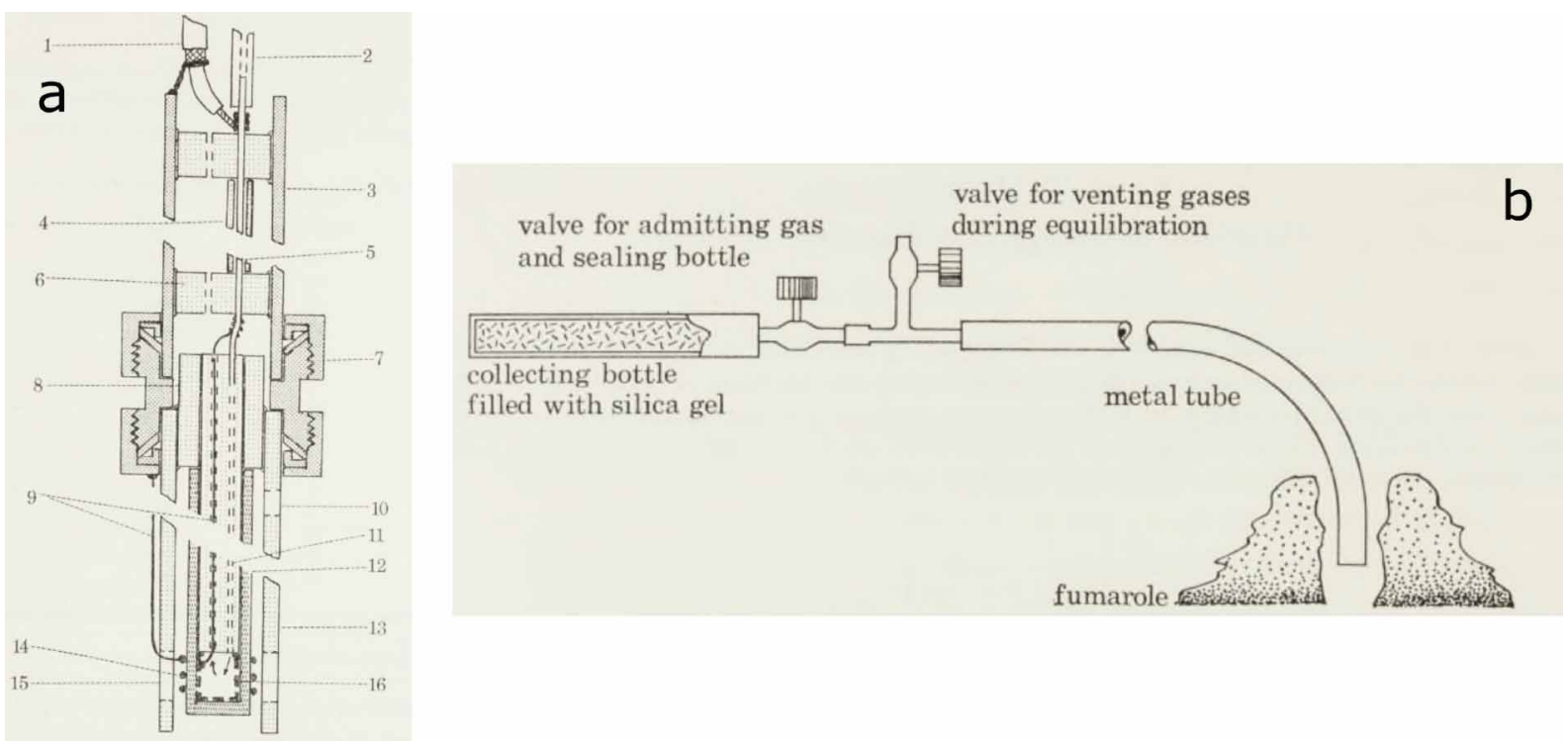

Figure 5. Some new instruments used during the 1971 eruption by Sato and Moore [1973]: a) the oxygen fugacity sensor probe; and by Huntington [1973]; b) volcanic gas collecting apparatus.

Another main feature of the 1971 eruption is related to a gradual, but significant, change in the composition of erupted magmas enriched in alkalis and in their quantity of volatiles [Viccaro and Cristofolini, 2008; Viccaro et al., 2011; Di Renzo et al., 2018 and references therein]. In fact, volcanism of Etna was fed by Na-alkalic magma from 220 ka ago up to the 1970s, but later and up to the present, the erupted products shifted to K-alkalic affinity [Corsaro and Pompilio, 2004 and reference therein]. In addition, the formation of SEC marks a significant increase in the frequency of eruptive events, mostly occurring in the eastern sector of the volcano and structurally connected to the newly formed crater [Cappello et al., 2019 and reference therein]. The main growth of the SEC cone is due to several lava fountain episodes between 1996 and 2001 [Behncke et al., 2006] and following to the SE shifting of the eruptive axes that generated a new large scoria cone, informally named New Southeast Crater [Behncke et al., 2014; De Beni et al., 2015, Corsaro et al., 2017], starting from 2007 during a series of lava fountaining episodes. Since 2017, the explosive activity has gradually produced the coalescence of the old and new cone of the SEC resulting in a SE elongated large composite stratocone [De Beni et al., 2020] becoming the highest peak of Etna, $3357 \mathrm{~m}$ a.s.1., following the eruptive activity of 2021 [Bollettino settimanale Etna, 2021]. During the recent activity of SEC of December 2020, the lava flows covered the last remains of the first phase of the 1971 eruption represented by the scoria cone of the Observatory vent (Figure 6), which has been dedicated to the memory of Gaetano Ponte following a proposal of Cucuzza Silvestri [Rittmann et al., 1971]. As a whole, the 1971 eruption represents, together with the major 1669 flank eruption, the volcanic events that have modified the eruptive behaviour of Etna in historical time [Branca and Abate, 2019]. For this reason, during the compilation of the new geological map of Etna, at 1:50.000 scale, the 1669 and 1971 eruptions were used to divide the volcanic products erupted in historical time [Torre del Filosofo formation of Branca et al., 2011]. They were grouped into three time intervals defined through the pinpointing of these main eruptive events marking significant periods of the eruptive activity evolution of the past 2 ka according to the present knowledge of volcano history [Branca et al., 2011].

\subsection{Historical considerations}

During the first phase of the 1971 eruption, lava flows from the Observatory vent destroyed one of the main structures dedicated to the study of the volcano, namely the Etnean Observatory. It was built in 1879 at an altitude of $2941 \mathrm{~m}$ on the southern flank of the volcano by the astronomer Pietro Tacchini (1838-1905). After a few years, the observatory was abandoned because the highly corrosive volcanic gases made the optical instrumentation useless due to the extreme proximity to the Central Crater. During his career, Gaetano Ponte spent a great deal of time restoring 


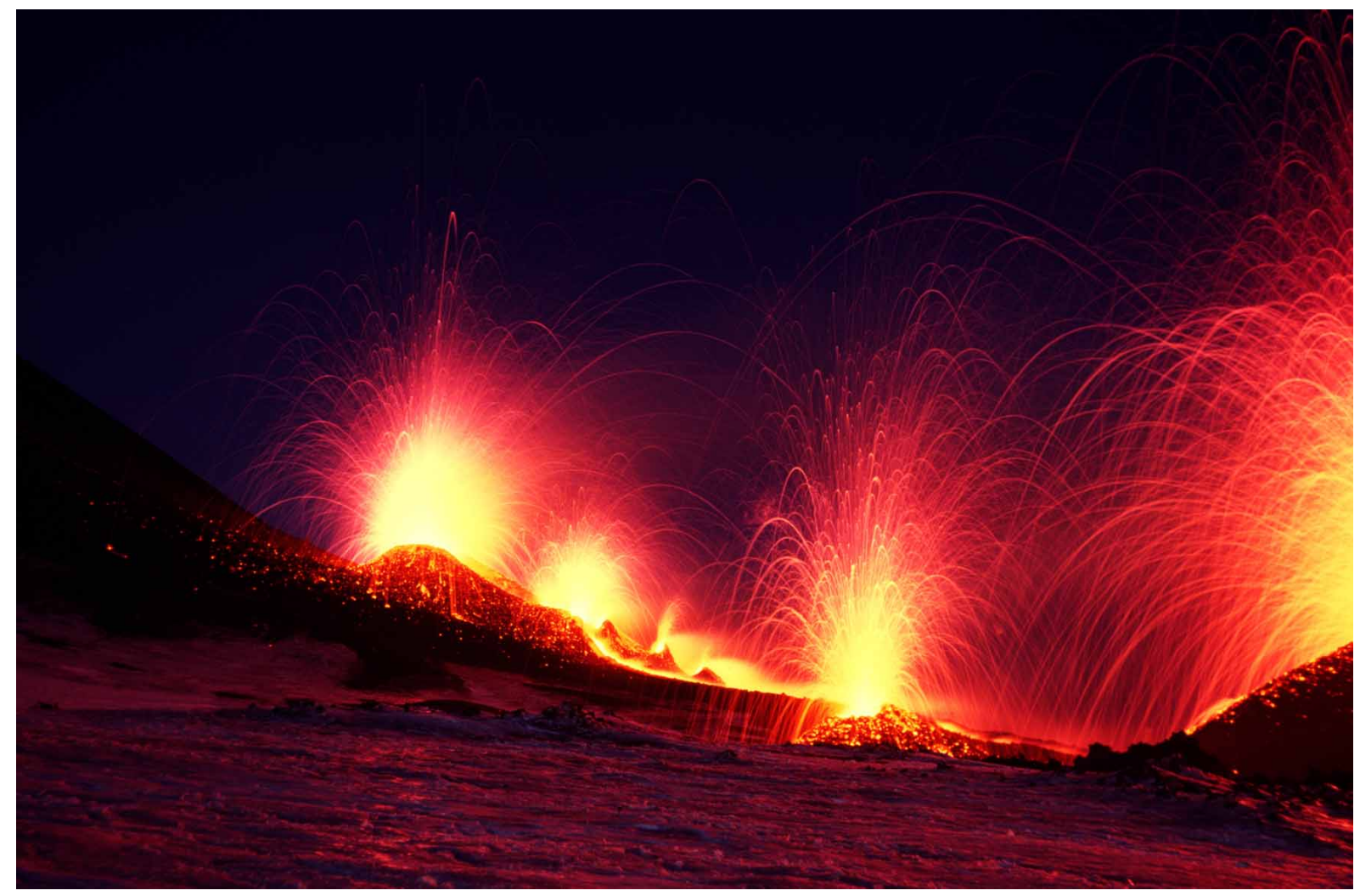

Figure 6. Image of the spectacular strombolian activity that characterized the Vulcaloro fissure, in the background, and Observatory fissure, in the foreground on the right (photograph of Bonaccorso, INGV, Osservatorio Etneo archive).

the observatory, which at the beginning was part of the Royal Astrophysical and Geodynamic Observatory of Catania, and was later annexed in 1926 to the chair of Volcanology of Catania University [Branca and Bonaccorso, 2005]. The observatory was equipped with heating, electric light and also running water that came from a condenser designed by Ponte and applied to the centuries-old fumarole called Vulcaloro, also covered by the 1971 lava flow. The Etnean Observatory, during the 1950s and 60s, was mainly used as a lodge by Italian and foreign researchers who in those years began to study the volcano assiduously. In addition, the lava flows destroyed the Etna cableway, for the first time causing damage to the tourist activities.

The second phase of the eruption led certain scientists to understand that the activity in progress was not typical of Etna's activities, both for the wide petrochemical evolution of the erupted magma [Rittmann et al., 1971] and for the considerable distance $(6 \mathrm{~km})$ between the degassing pit crater at $3000 \mathrm{~m}$ a.s.l and the effusive vent of Serracozzo. This aspect could not be explained [Tazieff and Le Guern, 1972] in Rittmann's classification of Etnean eruptions (terminal, subterminal, flank, eccentric) [Rittmann, 1964].

In general, it is evident from the sources available to us that the 1971 Etna eruption was studied in a very different way compared to the flank eruptions of previous decades. The presence in Catania of figures such as Rittmann, Tazieff and Marinelli, together with French and British teams, marked a significant shift towards a much more quantitative and multidisciplinary volcanology. In particular, the direction of the studies moved towards a physico-chemical approach that takes thermodynamics into account, allowing the measurement of aspects previously considered only qualitatively [Rittmann, 1963; Vincent, 1973; Tonani, 1995, Principe and Vezzoli, 2020; Musumeci et al., 2021]. This is evident when compared with the previous flank eruption of 1950-1951. Several local volcanologists observed this eruption (Abruzzese, Stix, Speranza and De Fiore) that was also occasionally investigated by Imbò and Tazieff [Imbò, 1951; Tazieff, 1951; Sessa, 2001], but only Cumin and Ponte, at the end of his career, studied and published scientific works [Cumin 1952-1954; Cumin, 1954; Ponte, 1954]. The methodological approach was mainly naturalistic, with much room given to the narration and description of the eruptive phenomena and petrographic analysis. The only quantitative data were related to the evaluations of the erupted products, although the map of the lava field is an 


\section{Stefano Branca et al.}

approximate drawing not reproduced on a topographic basis (see Figure 1). Finally, the interpretation on the structure of the magmatic feeder system and on the intrusive processes published by Ponte [1954] was still anchored to the models of the early 1900s (Figure 7a), as clearly evidenced by the comparison with the following schematic model of the feeder system by Guest [1973] (Figure 7b). Little further accompanies this information, which reflects the training of local researchers that followed the 1950-1951 eruption. This is a sign that not many steps forward had been made since the second half of the $19^{\text {th }}$ century compared to the methodological approach used by Silvestri. The real advance occurred only a decade later, with a progressive increase in studies until the 1971 eruption, which constituted a positive conjunction for the evolution of volcanological studies on Etna (Table 1). The multidisciplinary method, now consolidated, would then be enriched in the following decades by an increasingly advanced geophysical network - that at the time counted the Geophysical Observatory of Lipary built in 1967 [Di Prima et al., 2010] - thanks also to the work of the IIV Director Letterio Villari (1940-2021).
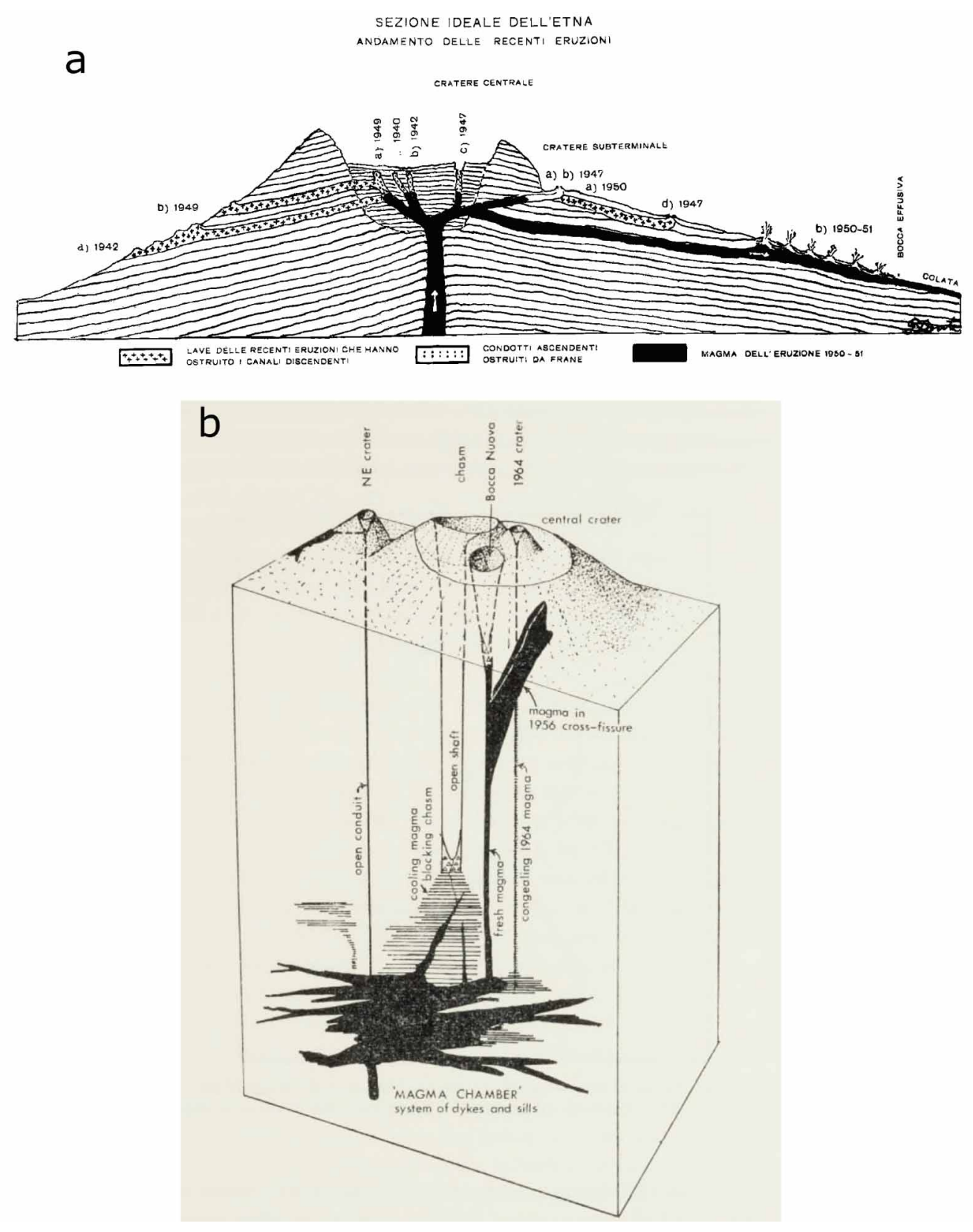

Figure 7. Comparison between the schematic models of the feeder system of Etna by Ponte (1954) realized for the 195051 eruption (a) and by Guest [1973] in which is reproduced a block diagram of the summit cone (b), showing the inferred distribution of magma within the volcano during 1971. 


\begin{tabular}{ccc} 
Field of study & Local & International \\
\hline Volcanologists & Italian & Italian, French, British, Americans \\
\hline Methodology & $\begin{array}{c}\text { Mainly descriptive, few } \\
\text { measurements }\end{array}$ & Multidisciplinary \\
\hline Sources & Few single-author articles & $\begin{array}{c}\text { Multi-author articles plus a volume of articles and discussions } \\
\text { arising from a study conference on the eruption }\end{array}$ \\
\hline
\end{tabular}

Table 1. Comparison between the studies and the methodologies applied to the 1950-51 and 1971 flank eruptions.

\section{Conclusive remarks}

In this paper, we have performed an interdisciplinary study on the 1971 flank eruption of Etna with the aim of highlighting the volcanological features of this event in the frame of the eruptive history of the volcano. At the same time, we have described the historical evolution of volcanological studies on Etna between the 1950s and 1970s in order to evidence the scientific context of that time. The main results from our re-examination of the 1971 eruption can be summarized as follows:

1971 eruption: a) Complex intrusive dynamics associated at the beginning of the eruption with several short radial dykes dissecting the summit cone SE slope, followed by a main horizontally intrusion consisting of a roughly $4.5 \mathrm{~km}$-long ENE trending dyke; b) significant deformation occurred in the upper part of the volcano during the first phase of the eruption inducing the movement of the east flank with the consequent activation of the seismogenic fault of Moscarello; c) formation of a new summit crater, later namely SE Crater.

Post-1971 eruption: a) increased frequency of summit and flank eruptions and associated output rate; b) change of chemical compositions of magma towards products richer in K; c) The SE Crater became the most active of the summit craters of Etna marking a remarkable change in the eruptive style of the volcano.

The 1971 eruption, for the history of volcanology, was the first important occasion on which the national and international scientific community realised the proposals of Rittmann, Tazieff and Marinelli. The multidisciplinary method used to study Etna's eruptions is still applied today and is still valid.

The growth of collaborations following the 1971 eruption led to an increasingly in-depth study of Etna, and since then the volcano has become one of the most studied in the world. INGV-Etnean Observatory is nowadays one of the most advanced scientific research centres engaged in the constant monitoring and surveillance of Etna's volcanic activities.

Acknowledgments. Thanks are due to the anonymous reviewers for their useful comments. The paper was funded by "Research programm" UNICT 2020-22, line 2 - EUROAD Project.

\section{References}

Abate, T., S. Branca and C. Monaco (2013). Le eruzioni dell'Etna nell'opera di Orazio Silvestri (1835-1890). Il disegno come strumento per l'osservazione scientifica, Caracol, Palermo, 132.

Aloisi, M., A. Bonaccorso and S. Gambino (2006). Imaging composite dike propagation (Etna, 2002 case), J. Geoph., Res.: Solid Earth, 111, B06404, doi:10.1029/2005JB003908.

Arculus, R.J. (1973). Recent submarine pillow lavas in the Catania area, eastern Sicily, Phil.Trans. R. Soc. London A, $274,153-162$. 


\section{Stefano Branca et al.}

Azzaro, R. and M.S. Barbano (1996). Relationship between seismicity and eruptive activity at Mt. Etna volcano (Italy) as inferred from historical record analysis: the 1883 and 1971 case histories. Ann. Geofis., 39, 2, https://doi.org/10.4401/ag-3981

Azzaro, R. and S. Barbano (1996). Relationship between seismicity and eruptive activity at Mt. Etna volcano (Italy) as inferred from historical record analysis: the 1883 and 1971 case histories, Ann. Geofis., 39, 2, 445-461, https://doi.org/10.4401/ag-3981

Azzaro, R., S. D’Amico and T. Tuvè (2011). Estimating the Magnitude of Historical Earthquakes from Macroseismic Intensity Data: New Relationships for the Volcanic Region of Mount Etna (Italy), Seismol. Res.Lett., 82, 4, 533-544. https://doi.org/10.1785/gssrl.82.4.533.

Azzaro, R., S. Branca, K. Gwinner and M. Coltelli (2012). The volcano-tectonic map of Etna volcano, 1:100.000 scale: an integrated approach based on a morphotectonic analysis from high-resolution DEM constrained by geologic, active faulting and seismotectonic data, Ital. J. Geosci., 131, 1, 153-170, doi:10.3301/IJG.2011.29.

Barberi, F. and F. Innocenti (1995). Giorgio Marinelli, Bollettino Soc. Geol. Ital., 114, 311-318.

Behncke, B., M. Neri, E. Pecora and V. Zanon (2006). The exceptional activity and growth of the Southeast Crater, Mount Etna (Italy), between 1996 and 2001, Bull. Volcanol. 69, 149-173. http://dx.doi.org/10.1007/s00445006-0061-x.

Behncke, B., S. Branca, R. Corsaro, E. De Beni, L. Miraglia and C. Proietti (2014). The 2011-2012 summit activity of Mount Etna: birth, growth and products of the new SE, crater. J. Volcanol. Geotherm. Res., 270, 10-21, http://dx.doi.org/10.1016/j.jvolgeores.2013.11.012.

Bollettino settimanale Etna 02/08/2021 - 08/08/2021, Rep. $\mathrm{N}^{\circ}$ 32/2021. https://www.ct.ingv.it/index.php/monitoraggioe-sorveglianza/prodotti-del monitoraggio/bollettini-settimanali-multidisciplinari

Bonaccorso, A., S. Calvari, M. Coltelli, C. Del Negro and S. Falsaperla (2004). Etna Volcano Laboratory. AGU (Geophysical monograph) 143, 384.

Bonaccorso, A. and S. Branca (2005). Fotografia storica alla luce del vulcano. Fondo fotografico Gaetano Ponte (18761955), Le Nove Muse, Catania, 196.

Bonaccorso, A. and P.M. Davis (2004). Modeling of ground deformation associated with recent lateral eruptions: Mechanics of magma ascent and intermediate storage at Mt. Etna, in Mt. Etna: Volcano Laboratory, Geophys. Monogr. Ser., 143, edited by Bonaccorso, A. et al., 293-306, AGU, Washington, D.C.

Bonforte, A., F. Guglielmino and G. Puglisi (2019). Large dyke intrusion and small eruption: The December 24, 2018 Mt. Etna eruption imaged by Sentinel-1 data, Terra Nova, 31, 405-412, doi: 10.1111/ter.12403.

Booth, B. and S. Self (1973). Rheological features of the 1971 Mount Etna lavas, Phil. Trans. R. Soc. Lond. A., 274, 99-106. Borrelli, G.A. (1670). Historia et meteorologia incendii Aetnaei anni 1669, in officina Dominici Ferri, Regio Iulio.

Branca, S. and P. Del Carlo (2004). Eruptions of Mt Etna during the past 3.200 years: a revised compilation integrating the Historical and stratigraphic records. In: "Etna Volcano Laboratory” Bonaccorso, Calvari, Coltelli, Del Negro, Falsaperla (Eds), AGU (Geophysical monograph) 143, 1-27.

Branca, S. and P. Del Carlo (2005). Types of eruptions of Etna Volcano AD 1670-2003: Implications for short-term eruptive behaviour, Bull. Volcanol., 67, 732-742.

Branca, S., M. Coltelli, G. Groppelli and F. Lentini (2011). Geological map of Etna volcano, 1:50,000 scale. Ital. J. Geosci., 130, 3, 265-291, doi:10.3301/IJG.2011.15.

Branca, S., E. De Beni and C. Proietti (2013). The large and destructive 1669 AD Etna eruption: reconstruction of the lava flow field evolution and effusion rate trend, Bull. Volcanol., 75, 694, 2-16, doi:10.1007/s00445-013-0694-5.

Branca, S., R. Azzaro, E. De Beni, D. Chester and A. Duncan (2015). Impacts of 1669 eruption and the 1693 earthquakes on the Etna Region, (Eastern Sicily, Italy): an example of recovery and response of a small area to extreme events, J. Volcanol. Geotherm. Res., 303, 25-40, doi:10.1016/j.jvolgeores.2015.07.020.

Branca S. and T. Abate (2019). Current knowledge of Etna's flank eruptions (Italy) occurring over the past 2500 years. From the iconographies of the XVII century to modern geological cartography. J. Volcanol. Geotherm. Res., 385, 159-178, doi:10.1016/j.jvolgeores.2017.11.004.

Candela, A. (2019). The early stages of uranium geology, Earth Sciences History, 38, 1, 137-149.

Cappello, A., G. Ganci, G. Bilotta, C. Corradino, A. Hérault and C. Del Negro (2019). Changing Eruptive Styles at the South-East Crater of Mount Etna: Implications for Assessing Lava Flow Hazards, Front. Earth Sci., 7, 213, doi:10.3389/feart.2019.00213.

Centre Haroun Tazieff, http://tazieff.fr/biographie/, [28.3.2021]. 
Chamberlin, T.C. (1890). The method of multiple working hypotheses, Science, 15, 92-97.

Chester, D.K., A. Duncan, J.E. Guest and C. Kilburn (1985). Mount Etna. The anatomy of a volcano, Stanford University Press, 404.

Corsaro, R. A. and M. Pompilio (2004). Magma Dynamics at Mount Etna. In: Bonaccorso, A, S. Calvari, M. Coltelli, C. Del Negro and S. Falsaperla (eds), Mount Etna Volcano Laboratory, AGU (Geophysical monograph series), 143, 91-110.

Corsaro, R. A., D. Andronico, B. Behncke, S. Branca, T. Caltabiano, F. Ciancitto, A. Cristaldi, E. De Beni, A. La Spina, L. Lodato, L. Miraglia, M. Neri, G. Salerno, S. Scollo and G. Spata (2017). Monitoring the December 2015 summit eruptions of Mt. Etna (Italy): implications on eruptive dynamics, J. Volcanol. Geotherm. Res., 341, 53-69, doi:10.1016/j.jvolgeores.2017.04.018.

Cristofolini, R. (1973). Recent trends in the study of Etna, Phil. Trans. R. Soc. Lond. A., 274, 17-35.

Cristofolini, R. (2016). From Natural History to Volcanology. An account on the development of studies on Mt. Etna at the University of Catania, Boll. Acc. Gioenia Sci. Nat., Catania, 49, 379, 23-38.

Cumin, G. (1952-1954). L’eruzione laterale etnea dal novembre 1950 al dicembre 1951, Atti Acc. Gioenia Sci. Nat., Catania, VI, 9, 123-133.

Cumin, G. (1954). L'eruzione laterale etnea del novembre 1950 - dicembre 1951, Bull. Volcanol., 15, 3-70.

De Beni, E., B. Behncke, S. Branca, I. Nicolosi, R. Carluccio, F. D’Ajello Caracciolo and M. Chiappini (2015). The continuing story of Etna's New Southeast Crater (2012-2014): evolution and volume calculations based on field surveys and aerophotogrammetry, J. Volcanol. Geotherm. Res., 303, 175-186, doi:10.1016/j.jvolgeores.2015.07.021.

De Beni, E., M. Cantarero, M. Neri and A. Messina (2020). Lava flows of Mt Etna, Italy: the 2019 eruption within the context of the last two decades (1999-2019), J. Maps, doi:10.1080/17445647.2020.1854131.

Di Prima S., M. Manni, M. Marturano, D. Patanè and A. Pellegrino (2010). L’Osservatorio Geofisico di Lipari e i 40 anni della Rete Sismica Permanente del Tirreno meridionale, Quaderni di Geofisica, 81, 1-37.

Di Renzo, V., R.A. Corsaro, L. Miraglia, M. Pompilio and L. Civetta (2018). Long and short-term magma differentiation at Mt. Etna as revealed by SrNd isotopes and geochemical data, Earth Sci. Rev. 190, 112-130, doi:10.1016/j.earscirev.2018.12.008.

Downes, M.J. (1973). Some experimental studies on the 1971 lavas from Etna, Phil. Trans. R. Soc. Lord. A., 274, 55-62.

Elskens I., H. Tazieff and F. Tonani (1964). A new method for gas analysis in the field, I.U.G.G. Gen. ass., Bull. Volc., XXVII, 1-4.

Elskens I., H. Tazieff and F. Tonani (1969). Investigations Nouvelles sur les Gaz Volcaniques, Bull. Volc., vol. XXXII, 522574.

Gauthier, F. (1973). Field and laboratory studies of the rheology of Mount Etna lava, Phil. Trans. R. Soc. Lord. A., 274, 83-98.

Grindley, G.W. (1973). Structural control of volcanism at Mount Etna, Phil. Trans. R. Soc. Lond. A, 274, 165-175.

Guest, J.E. (1973). The summit of Mount Etna prior to the 1971 eruption, Phil Trans R Soc Lond. A, 274, 63-78.

Guest, J.E., P. Cole, A. Duncan and D. Chester (2003). Volcanoes of Southern Italy, The Geological Society, London, 284.

Guest, J.E. and R.R. Skelhorn R. R. (eds.) (1973). Mount Etna and the 1971 eruption, Phil. Trans. R. Soc. London A 274, 1-179.

Guidoboni, E., C. Ciuccarelli, D. Mariotti, A. Comastri and M. G. Bianchi (2014). L'Etna nella Storia. In: Catalogo delle eruzioni dall'antichità alla fine del XVII secolo, Bononia University Press, Bologna, 1122.

Harris, A., A. Steffke, S. Calvari and L. Spampinato (2011). Thirty years of satellite-derived lava discharge rates at Etna: Implications for steady volumetric output, J, Geophys. Res.: Solid Earth, 116, B8, https://doi.org/10.1029/2011JB008237.

Huntington, A. T. (1972). The eruption of Mount Etna, 1971, Spring, 60, 237, 107-119.

Huntington, A. T. (1973). The collection and analysis of volcanic gases from Mount Etna, Phil. Trans. R. Soc. London A., 274, 119-128.

Imbò, G., 1951, Temperature d'irrigidimento di attuali lavi etnee, Rend. Accad. Sc. Fis. e Mat. Della Soc. Naz. di Sc., Lett. e Arti in Napoli, 4, 18, 1-4.

Kilburn, C., D. Chester, A. Duncan, R. Lopes, D. McNally, J. Murray, E. Stofan and D. Timm (2012). https://www.geolsoc.org.uk/About/History/Obituaries-2001-onwards/Obituaries-2012/John-Edward-Guest, [28.3.2021]. 


\section{Stefano Branca et al.}

Kuhn, W. and A. Rittmann (1941). Über den Zustand des Erdinnern und seine Entstehung aus einem homogenen Urzustand, Geologische Rundschau, 32, 215-256.

Le Guern, F., http://www.lave-volcans.eu/intro.html, [27.3.2021].

Le Guern, F. (1972). Etudes dynamique sur la phase gazeuse eruptive, Thèse de 3ème cycle, R 4383, C.E.N. Saclay, Gif sur Yvette.

Le Guern, F. (1973). The collection and analysis of volcanic gases, Phil. Trans. R. Soc. Lond. A., 274, 129-135.

Lockwood J.P. and R. W. Hazlett (2010). Volcanoes: Global Perspectives, Wiley-Blackwell, 550.

Mattia, M., V. Bruno, E. Montgomery-Brown, D. Patanè, G. Barberi and M. Coltelli (2020). Combined Seismic and Geodetic Analysis Before, During, and After the 2018 Mount Etna Eruption. Geochemistry, Geophysics, Geosystems, AGU, 21, 9, https://doi.org/10.1029/2020GC009218

Morello, N. (2001). Introduzione in Borelli, G. A., Storia e meteorologia dell'eruzione dell'Etna del 1669, Giunti, Firenze, 5-47.

Musarra, A. (2018). Una vita per l'Etna. Orazio Silvestri vulcanologo fiorentino (1835-1890). Caracol, Palermo, 272.

Musumeci D., S. Branca and L. Ingaliso (2021). Magmatological Tectonics: Alfred Rittmann's paradigm, Earth Sciences History, 40, 1, 266-281.

Ponte G. (1917). Meccanismo delle eruzioni etnee, in Zeitschrift für Vulcanologie. vol. 1.

Ponte G. (1953). Sull'eruzione etnea del 1950-51, Bull Volcanol., II, 13, 121-128.

Principe C. and L. Vezzoli (2020). Monte Amiata volcano (Tuscany, Italy) in the history of volcanology: 2-its role in the definition of "ignimbrite" concepts and in the development of the "rheoignimbrite" model of Alfred Rittmann, Rendiconti Lincei, Scienze Fisiche e Naturali, 31, 539-561, https://doi.org/10.1007/s12210-02000932-8.

Recupero, G. (1815). Storia naturale e generale dell'Etna, 2 voll. Regia Università degli Studi, Catania.

Riuscetti, M. and R. Di Stefano (1971). Il Terremoto di Macchia (Catania), Boll. Geof. Teor. Appl., 13, 150-164.

Rittmann, A. (1931). Vulkanische Glutwolken und Glutlawinen: Naturwissenschaften, 19, 51, 1017-1020.

Rittmann, A. (1963). I progressi recenti della vulcanologia e le ricerche sull'Etna, Bollettino dell'Accademia Gioenia di Catania, IV, 7, 227-239.

Rittmann, A. (1964). Vulkanismus und Tektonik des Ätna, Geologische Rundschau, 53, 788-800, https://doi.org/10.1007/BF02054564

Rittmann, A. (1973). Structure and evolution of Mount Etna, Phil. Trans. R. Soc. Lond. A., 274, 5-16.

Rittmann, A. (1981). Vulkane und irhe Tätigkeit, Stuttgart, Ferdinand Enke Verlag, 399.

Rittmann, A., V. Gottini Grasso, W. Hewers, H. Pichler and R. Stengelin (1973). Stable Mineral Assemblages of Igneous Rocks. A Method of Calculation, Berlin and Heidelberg, Springer Verlag, 264, doi:10.1007/978-3-642-65482-4.

Rittmann, A., R. Romano and C. Sturiale (1971). L’eruzione etnea dell'Aprile-Giugno 1971. Atti Acc. Gioenia Sc. Nat. Catania, 7, 3, 3-29.

Romano, R. (1981). Annual report of the world volcanic eruption in 1978, Bull. Volc. Erupt., 18, 8-10, In suppl. Boll. Volcanol., 44, 1. 1981.

Romano, R. (ed) (1982). Mount Etna volcano, Mem. Soc. Geol. Ital., 23.

Romano, R. and C. Sturiale (1973). Some considerations on the magma of the 1971 eruption, Phil. Trans. R. Soc. Lond. A., 274, 37-43.

Romano, R. et alii (1979). Carta geologica del Monte Etna, scala 1:50.000. Progetto Finalizzato Geodinamica, Istituto Internazionale di Vulcanologia-C.N.R. (Catania)., Memorie Soc. Geol. Ital., 23, (1982).

Rovida, A., M. Locati, R. Camassi, B. Lolli and P. Gasperini (2020). The Italian earthquake catalogue CPTI15. Bulletin of Earthquake Engineering, 18, 7, 2953-2984, https://doi.org/10.1007/s10518-020-00818-y.

Sartorius Von Waltershausen, W. (1848-61). Atlas des Aetna, S. Schmidt (v. 1), Berlin, Geografisches Institut (voll. 2-8), Weimar (9).

Sato, M. and J.G. Moore (1973). Oxygen and sulphur fugacities of magmatic gases directly measured in active vents of Mount Etna, Phil. Trans. R. Soc. London A., 274, 137-146.

Self, S. and R. S. Sparks (2006). GEORGE PATRICK LEONARD WALKER 2 March 1926 - 17 January 2005, Biogr. Mems Fell. R. Soc., 52, 423-436.

Sessa, P. (2001). Milo e l'eruzione del 1950. Ricostruzione di un evento, immagini di un'epoca, L'Almanacco Editore, 80.

Silvestri, O. (1866). Sulla eruzione dell'Etna nel 1865. Studi geologici e chimici, Nuovo Cimento, Pisa, Tomo XXI-II, 
Fasc. Feb-Mar.

Silvestri, O. (1883). Sulla esplosione etnea del 22 marzo 1883 in relazione ai fenomeni vulcanici (geodinamici ed eruttivi) presentati dall'Etna durante il quadriennio compreso dal gennaio 1880 al dicembre 1883, Atti Acc. Gioenia Sci. Nat. Catania, III, 17, 238-431.

Silvestri, O. (1886). Sulle eruzioni Centrale ed Eccentrica dell’Etna scoppiate il 18 e 19 Maggio 1886 . $\mathrm{I}^{\circ}$ e $2^{\circ}$ Rapporto al Regio Governo, Niccolò Giannotta Editore, Catania, 32.

Silvestri, O. (1893). L’eruzione dell'Etna del 1886, Atti Acc Gioenia Sc. Nat. Catania 4, VI, 36 pp.

Smithsonian Institution Center For Short-Lived Phenomena. (1972), 1971 Annual Report, Mt. Etna Volcanic Activity, 61-69.

Tanguy, J.C. (1973). The 1971 Etna eruption petrography of the lavas. Phil. Trans. R. Soc. London A., 274, 79-82.

Tanguy, J.C. (1981). Les éruptions historiques de l'Etna: chronologie et localisation, Bull. Volcanol. 44-3, 585-640.

Tanguy, J.C., M. Condomines, S. Branca, S. La Delfa and M. Coltelli (2012). New archeomagnetic and 226Ra-230Th dating of recent lavas for the Geological map of Etna volcano, Ital. J. Geosci., 131, 2, 241-257, doi: 10.3301/IJG.2012.01.

Tanguy, J. C. and R.L. Wilson (1973). Palaeomagnetism of Mount Etna, Phil. Trans. R. Soc. Lond. A. $274,163$.

Tazieff, H. (1951). Cratères en fue, Arthaud, Paris-Grenoble, 249.

Tazieff, H. (1974). L’Etna e i vulcanologi, Arnoldo Mondadori, Milano, 187.

Tazieff, H. (1973). Structural implications of the 1971 Mount Etna eruption, Phil. Trans. R. Soc. Lond. A. 274, 79-82. Tazieff, H. (1984). Sur l'Etna, Flammarion, Paris, 251 pp.

Tazieff, H, G. Marinelli, F. Barberi and J. Varet (1969). Géologie de l’Afar septentrional, première expédition du CNRS France et du CNR Italie (décembre 67 - février 68), Bull. Volc., vol. XXXIII, 1039-1072.

Tazieff, H. and F. Le Guern (1971). Signification tectonique et mécanisme de l'éruption d'avril-mai-juin 1971 de l'Etna, C R Acad Sci Paris 272, 3252-3255.

Tonani, F. (1995). Epistemologia ed insegnamento della Chimica Fisica nel corso di laurea in Scienze Geologiche, Nota I, Rend. Fis. Acc. Lincei, s. 9, 5, 49-63.

Viccaro, M. and R. Cristofolini (2008). Nature of mantle heterogeneity and its role in the short-term geochemical and volcanological evolution of Mt. Etna (Italy), Lithos 105, 272-288. doi:10.1016/j.lithos.2008.05.001.

Viccaro, M., E. Nicotra, I.L. Millar and R. Cristofolini (2011). The magma source at Mount Etna volcano: perspectives from the Hf isotope composition of historic and recent lavas. Chem. Geol. 281, 343-351. doi:10.1016/j.chemgeo. 2010.12.020.

Vincent, E. A. (1973). Introduction, Phil. Tram. R. Soc. Lond. A., 274, 3.

Wadge, G. and J.E. Guest (1981). Steady-state magma discarge at Etna 1971-1981, Nature 255, 385-387.

Walker, G.P.L., (1973a). A brief account of the 1971 eruption of Mount Etna, Phil. Trans. R. Soc. London A., 274, 177-179.

Walker, G.P.L., (1973b), Lengths of lava flows, Phil. Trans. R. Soc. London A., 274, 107-118.

Walter, T.R., V. Acocella, M. Neri and F. Amelung (2005). Feedback processes between magmatic events and flank movement at Mount Etna (Italy) during the 2002-2003 eruption, J. Geophys. Res.: Solid Earth, 110, B10, https://doi.org/10.1029/2005JB003688.

*CORRESPONDING AUTHOR: Stefano BRANCA,

Istituto Nazionale di Geofisica e Vulcanologia,

Osservatorio Etneo-Sezione di Catania,

e-mail: stefano.branca@ingv.it

(c) 2021 the Author(s). All rights reserved.

Open Access. This article is licensed under a Creative Commons Attribution 3.0 International 